\title{
GÊNERO E SEXUALIDADES EM TEMPOS INSTÁVEIS: MÍDIAS DIGITAIS, IDENTIFICAÇÕES E CONFLITOS.
}

\author{
GENDER AND SEXUALITIES IN UNSTABLE TIMES: \\ DIGITAL MEDIA, IDENTIFICATIONS AND CONFLICTS.
}
GÉNERO Y SEXUALIDAD EN TIEMPOS DE INESTABILIDAD:
DIGITAL MEDIA, IDENTIFICACIÓNES Y CONFLICTOS.

Anna Paula Vencato ${ }^{1}$

\begin{abstract}
RESUMO
Neste texto busco versar sobre o modo como as mídias digitais - com foco nas páginas da internet, blogs e redes sociais - e o cenário político nacional se articulam, embasam e desembocam em polarizações e questionamentos sobre as normas sociais, os preconceitos e as exclusões. Proponho-me a pensar, a partir das redes sociais, na ampliação do debate sobre "liberdade de expressão x discurso de ódio", para além da emergência de novos sujeitos políticos que reivindicam outras identificações para além das já estabelecidas (em especial quanto às identidades fixas relativas ao gênero e às sexualidades).
\end{abstract}

PALAVRAS-CHAVE: Liberdade de expressão. Discurso de ódio. Conflito. Mídias digitais. Gênero. Sexualidades.

\section{ABSTRACT}

I intend to traverse in this text on how digital media - focusing on websites, blogs and social networks - and the national political scene articulate, underpin and end at polarizations and questions about social norms, prejudices and exclusions. I propose to think, from the social networks, the expansion of the debate on "freedom of speech $x$ hate speech", in addition to the emergence of new political actors who claim other identifications in addition to the already established ones (especially as regards fixed identities related to gender and sexuality).

KEYWORDS: Freedom of speech. Hate speech. Conflict. Digital medias. Gender. Sexualities.

\section{RESUMEN}

En este artículo voy a discutir cómo los medios digitales - centrándose en páginas web, blogs y redes sociales y la escena política nacional es articulado, subyace y termina en polarizaciones y preguntas acerca de las normas sociales, los prejuicios y las exclusiones. Propongo pensar, desde las redes sociales, la ampliación del debate sobre la "libertad de expresión X discurso de odio", además de la aparición de nuevos actores políticos que afirman varias otras identificaciones de los ya establecidos (en particular con respecto a identidades fijas relacionadas con el género y la sexualidad).

PALABRAS CLAVE: Libertad de expresión. Discurso de odio. Conflicto. Medios digitales. Género. Sexualidades.

\footnotetext{
${ }^{1}$ Doutora em Sociologia e Antropologia - Universidade Federal do Rio de Janeiro (UFRJ) - Rio de Janeiro, RJ Brasil. Professora adjunta - Universidade Federal de Minas Gerais (UFMG) - Belo Horizonte, MG - Brasil.
}

(C) ETD- Educação Temática Digital $\quad$ Campinas, SP $\quad$ v.19 $\quad$ n.4 $\quad$ p. 808-823 $\quad$ out./dez. 2017




\title{
INTRODUÇÃO
}

\begin{abstract}
Hoje em dia essa coisa de internet, as pessoas falam o que vem na cabeça. E a primeira vez que eu vi isso eu não sabia como era o jogo ainda. Eu fiquei espantadíssimo: o que que tão falando aí?! (risos) Porque o artista, geralmente ele acha que é muito amado... Porque ele anda nas ruas: 'Bom dia! - Bom dia!'... Cheio de carinho... 'Fica com Deus!' ... aquela história que tem na música... e vai, faz o show, é aplaudido e tal... ele se acha... ele vai prá internet, ele é odiado! Ele lê as piores coisas (gargalhadas)... Então, eu a primeira vez que eu vi, eu sei que foi uma notícia assim e aí eu vi 'comentários'... eu nunca tinha entrado nisso (risos)! Aí quando você vê: 'esse velho!' (gargalhadas)... 'o que que o álcool não faz com uma pessoa!'... pô, você viu a injustiça? Porque eu já nem bebo mais. 'O que que esse velho tá fazendo aí?' (gargalhadas). Que você vai fazer o quê né? Aí as pessoas têm uma raiva... existe uma raiva... mas você não vai ficar com raiva de quem tem raiva. Tem que deixar prá lá. Não pode ficar triste com isso, nem morrer... se morrer é pior! Se morrer vai dizer: 'já morreu tarde!', 'já vai tarde!' (gargalhadas). Chico Buarque ${ }^{2}$.
\end{abstract}

Leonardo Sakamoto, jornalista brasileiro e doutor em Ciência Política, (re)conhecido por seu alinhamento com "a esquerda", escreve em seu blog ${ }^{3}$, em setembro de 2014, uma coluna sobre um dos episódios mais pitorescos da eleição presidencial ${ }^{4}$ que se encontrava

\footnotetext{
2 Transcrição de vídeo disponível online em: <https://www.youtube.com/watch?v=n5LuD2CFhYE>. Acesso em 11 de agosto de 2015.

${ }^{3}$ Blogs funcionam como diários virtuais ou espaços na internet em que diferentes pessoas podem publicar pontos de vista ou temas que lhes sejam de interesse. Há blogs independentes, com patrocinadores ou dentro de grandes portais da internet ou de veículos jornalísticos. Na prática, qualquer pessoa com acesso à internet pode ter um blog, mas o fluxo de acessos diferencia-se a partir de temas, propostas, etc. Em outras palavras, há uma plasticidade nos usos dessa ferramenta e nas formas como são acessadas por diferentes leitores/as. Pode-se dizer, ainda, nos termos de Yochai Benkler que "a internet cria as possibilidades de participação em uma Esfera Pública, mas não torna, imediatamente, todos os cidadãos em pessoas interessadas nos problemas coletivos" (apud Martino, 2015, p. 113). Defino mídias digitais, conforme Felipe A. Padilha (2015), como o "conjunto articulado de tecnologias da informação e seus suportes que englobam, inclusive, os dispositivos tecnológicos que permitem o acesso à internet, tais como computadores, smartphones e tablets." (p. 12, grifos do autor).

Utilizarei ao longo do texto o termo "redes sociais" como sinônimo de "serviços de redes sociais". Isso porque essas plataformas, conforme a proposta de danah $\mathrm{m}$. boyd e Nicole B. Ellison (2007), aplicativos e redes se configuram em serviços que possuem mediação (são empresas que possuem leis e moldam suas plataformas e os usos possíveis delas) e, além disso, fornece uma amplitude maior uma vez que estou optando por me referir a elas genericamente e não me debruçando especificamente sobre uma ou outra rede disponível atualmente. $\mathrm{N}$. da A.: o nome de dana $\mathrm{m}$. boyd aparece grafado em letras minúsculas conforme reivindicado pela autora em sua página da internet. (Disponível em: <http://www.danah.org/name.html>. Acesso em: 02 de novembro de 2016).

${ }^{4}$ Para uma análise do pleito eleitoral de 2014 ver o dossiê "Forum 2014 Elections" da revista Brazilian Political Science Review,. vol.9 no.1 São Paulo Jan./Apr. 2015. Para uma análise de como os candidatos à presidência fizeram uso das mídias digitais (especialmente suas contas na plataforma twitter) ver o artigo de Raquel Recuero (2016).
} 
curso no Brasil". Na ocasião, publica uma coluna sob o título de "A homofobia de Levy Fidelix doeu tanto quanto o silêncio dos $\operatorname{candidatos"~}^{\prime 6}$, que tratava das declarações deste candidato acerca de uma pergunta sobre direitos de Lésbicas, Gays, Bissexuais, Travestis e Transexuais (LGBT). Sakamoto relata o ocorrido da seguinte maneira:

Um dos pontos mais baixos da campanha presidencial foi protagonizado por Levy Fidelix (PRTB), na madrugada desta segunda (29), durante o debate dos presidenciáveis organizado pela TV Record.

Questionado por Luciana Genro sobre direitos homoafetivos, ele soltou um rosário de impropérios que fariam corar até os mais fundamentalistas dos parlamentares religiosos. Começou afirmando que 'dois iguais não fazem filho', que 'aparelho excretor não reproduz' e ainda teve tempo para comparar homossexuais a quem pratica o crime de pedofilia. Ao final, conclamou: 'Vamos ter coragem! Nós somos maioria! Vamos enfrentar essa minoria. Vamos enfrentá-los'.

E, depois, tece algumas considerações sobre o episódio, dentre elas uma em que afirmava:

Nas redes sociais, parte dos leitores apoiaram Levy Fidelix 'por ele ter a coragem de dizer o que pensa'. Isso não é coragem, é idiotice. Se ele pensa aquele pacote de sandices, que guarde para si e não propague isso em uma rede nacional de TV, concessão pública, sendo visto por milhões de pessoas, difundindo e promovendo o ódio contra pessoas.

Na época, o Blog de Sakamoto tinha a sessão de comentários abertos, recurso que mais tarde deixou de existir, justificado pela existência de cada vez mais frequentes, personalizadas e bastante detalhadas ${ }^{7}$ ameaças ao autor do blog e, também, a seus familiares. A coluna seguinte, chamada "Caso Levy: A diferença entre emitir opinião e

\footnotetext{
${ }^{5}$ É importante que se diga que os debates suscitados na ocasião, em especial os de intolerância, tem desdobramentos até o presente momento na sociedade brasileira, envolvendo casos de xenofobia (com relação a estrangeiros, mas também à migrações internas), intolerância religiosa e discriminações/violências contra LGBTs. Foge à proposta deste texto uma análise acerca dos posicionamentos e demandas do movimento LGBT ou de pessoas LGBT acerca deste debate à época. O que interessa ao debate aqui proposto é justamente como a partir do acesso às mídias digitais é possível a articulação discursos que podem ser vistos como mais ou menos democráticos e os limites e possibilidades de entendê-los como liberdade de expressão e/ou discursos de ódio.

${ }^{6}$ SAKAMOTO, Leonardo. A homofobia de Levy Fidelix doeu tanto quanto o silêncio dos candidatos. Blog do Sakamoto, 29 de setembro de 2014. Disponível em: <http://blogdosakamoto.blogosfera.uol.com.br/2014/09/29/a-homofobia-de-levy-fidelix-doeu-tanto-quantoo-silencio-dos-candidatos/>. Acesso em 11 de agosto de 2015.

${ }^{7}$ Estes comentários contavam com ameaças ao autor e sua família, além de publicações com o endereço de Sakamoto e familiares. Diante dos diversos episódios de mensagens que recebeu enquanto sua coluna esteve aberta para comentários em maio de 2016 Sakamoto lançou um livro chamado "O que aprendi sendo xingado na internet".
} 
proferir discurso de ódio" ${ }^{8}$ dialoga com um dos comentários postados na matéria em que critica o ocorrido no debate entre presidenciáveis. Publica o printscreen ${ }^{9}$ com o comentário de um internauta dizendo que responderia "à mensagem educadérrima e super chique do leitor Wagner", que preservara "sobrenome e o avatar ${ }^{10}$ do leitor para evitar o bullying" e afirmando que "assim como você, muita gente na internet também confunde opinião com discurso de ódio". Transcrevo a troca de mensagens entre leitor e Sakamoto publicada:

Leitor: Seu ridículo, critica a opinião do Levir mas pode dar a sua livremente né?? Onde esta a democracia? Seu comunista de merda, você pode e deve ter sua opinião,mas desmerecer e dizer que o outro não pode dar sua opinião é típico de gentinha como você, vai morar em Cuba, saia da internet, não use telefone, vai viver na caverna, seu comunista de merda ${ }^{11}$. (29 set. 2014, 15h29)

Sakamoto: Wagner, seu lindo [pictograma de coração] (29 set. 2014, 15h51)

Reitera que frequentemente este é "um erro bem comum quando você não está acostumado às regras do debate público de ideias" e que o anonimato viabilizado pela internet "traz aquela sensação quentinha de segurança e, por conta disso, não raro, as pessoas extrapolam", uma vez que mesmo que não seja impossível, a identificação de quem fala seja menos simples.

Segue-se a este início também jocoso uma reflexão de Sakamoto sobre a diferença entre liberdade de expressão e discurso de ódio, acerca da não existência de direitos fundamentais absolutos e da ideia de que pessoas como Levy Fidelix incitam às violências e discriminações contra as minorias - no caso, LGBTs - mesmo que digam que não o façam. Nesse contexto, o autor coaduna as ideias de Luis Antonio Baptista (1999) acerca dos

\footnotetext{
${ }^{8}$ SAKAMOTO, Leonardo. Caso Levy: A diferença entre emitir opinião e proferir discurso de ódio. Blog do Sakamoto, 30 de setembro de 2014. Disponível em:

http://blogdosakamoto.blogosfera.uol.com.br/2014/09/30/caso-levy-a-diferenca-entre-emitir-opiniao-eproferir-discurso-de-odio/>. Acesso em: 11 de agosto de 2015.

${ }^{9}$ Printscreen ou Captura de tela é uma espécie de fotografia feita do que está na tela de um computador ou outro aparelho eletrônico a partir do acionamento de uma ou mais teclas deste.

${ }^{10}$ Ou imagem que o internauta escolheu para representá-lo em seu perfil online. Pode ser uma foto real ou alguma outra imagem, como uma personagem de desenho animado, uma bandeira, uma paisagem, etc.

${ }^{11}$ Desde o pleito eleitoral para as prefeituras que ocorreu em 2012 temos observado uma série de categorias acusatórias relacionadas à posições políticas mais vanguardistas ou conservadoras tomarem corpo no Brasil. Dentre elas aparece uma ressignificação do termo "comunista", que não necessariamente é aplicada a pessoas com alinhamento com esta perspectiva política, mas foi ampliada a qualquer pessoa identificada com a esquerda. O termo "vermelho" também dialoga com esta leitura do termo "comunista". Ainda, categorias como "coxinha" (para designar pessoas que defendem ideiais tidos como de "direita", como a meritocracia, o estado mínimo, o fim de programas sociais, etc.) e "esquerda caviar" (para se referir a pessoas que defendem ideais à esquerda mas consomem bens tidos como "de elite", como iphones, roupas de marcas famosas, bebidas/restaurantes caros, etc.) têm sido frequentemente utilizados como categorias de acusação.
} 
"amoladores de facas", que seriam aqueles indivíduos cujos discursos fomentam as violências que atingem especificamente certas coletividades. Em suas palavras:

Como já disse aqui, pessoas como Levy Fidelix dizem que não incitam a violência. Não é a mão delas que segura a faca ou o revólver, mas é a sobreposição de seus discursos ao longo do tempo que distorce o mundo e torna o ato de esfaquear, atirar e atacar banais. Ou, melhor dizendo, "necessários", quase um pedido do céu. São pessoas como ele que alimentam lentamente a intolerância, que depois será consumida pelos malucos que fazem o serviço sujo.

O texto de Sakamoto é exemplar de um debate que importa e, de certo modo, muito falado, mas pouco analisado atualmente: aquele que versa sobre a liberdade de expressão como direito fundamental e seus (ab)usos nas redes sociais, os quais eventualmente resvalam na manutenção de preconceitos e violências que atingem especificamente certas populações: as minorias sociais. Para fins de guiar a análise, pautei-me no modelo proposto por Max Gluckman (1987), que propõe como modelo de análise uma descrição diacrônica, em que se torna possível, através da reconstrução de processos sociais de um dado evento ou situação compreender como dado grupo ou sociedade se pensa, se articula e quais são as questões que fazem com que aquelas pessoas signifiquem de uma forma ou de outra aquilo que fazem. A partir dessa descrição pinçarei os elementos que darão as bases para os argumentos desenvolvidos ao longo do texto.

Proponho então, a partir do debate do blog de Sakamoto, uma reflexão acerca das intersecções entre gênero ${ }^{12}$, sexualidade, mídias e direitos no contexto brasileiro atual. Ainda, seguindo a pista de Baptista (2011), que afirma que falar apenas em preconceitos seria ingênuo e poderia remeter, inadvertidamente, na lógica do "ponto de vista" ou da "boa/má consciência". Deste modo, conforme este autor,

O autoritarismo dos "pontos de vista" funda-se no esvaziamento da implicação coletiva e da construção histórica e sociopolítica do olhar e do outro. 0 preconceito, remetido a uma questão pessoal esvazia suas tramas com o poder, sua eficácia política na manutenção e na desqualificação dos modos de existir (2011, p. 48).

\footnotetext{
12 Para fins de delimitação conceitual, lanço mão neste texto da proposta de Judith Butler (2003), para quem "o gênero não deve ser meramente concebido como a inscrição cultural de significado num sexo previamente dado (uma concepção jurídica); tem de designar também o aparato mesmo de produção mediante o qual os próprios sexos são estabelecidos. Resulta daí que o gênero não está para a cultura como o sexo para a natureza; ele também é o meio discursivo/cultural pelo qual 'a natureza sexuada' ou 'um sexo natural' é produzido e estabelecido como 'pré-discursivo', anterior à cultura, uma superfície politicamente neutra sobre a qual age a cultura" (p. 25, grifos da autora). Para a autora, ainda, torna-se impossível separar gênero das interseç̧ões políticas e culturais - compreendidas em suas modalidades sexuais, étnico-raciais, de classe e religiosas - em que este é produzido e perpetuado (p. 20).
} 
Especificamente, pretendo versar ao longo deste texto sobre o modo como as mídias digitais - com foco nas páginas da internet, blogs e redes sociais - e o cenário político nacional se articulam, embasam e desembocam em polarizações e questionamentos sobre as normas sociais, os preconceitos e as exclusões. É preciso reconhecer, de qualquer modo, que essas instâncias constituem um espaço relacional (MCQuire, 2011). A noção de espaço relacional pode ser entendida como

[...] a condição do espaço social modelado pela experiência simultânea de velocidades radicalmente diversas: a sobreposição do que Virilio (1995, p. 144) chamou de velocidade "metabólica" do corpo, velocidade mecânica relativa dos veículos e a velocidade da luz "absoluta" das mídias e tecnologias de comunicação. O espaço relacional vem à tona quando a primazia, outrora dada à estabilidade dos objetos materiais, é re-emoldurada pelas relações variáveis estabelecidas entre velocidades distintas. (McQuire, 2011, p. 59).

O debate sobre o gênero e as sexualidades tem se entrelaçado nesse contexto dando voz e visibilidade a novos sujeitos políticos, assim como tem revitalizado e criado novas tensões. Isso pode ser visto através dos posicionamentos divergentes acerca de questões diversas, que vão desde a política praticada pelo Estado, passando pelos "direitos das minorias" e alcançando embates sobre questões que são frequentemente associadas ao reino do "privado". Um exemplo expressivo desse processo é o embate em torno da vivência cotidiana das homossexualidades ou transexualidades. Alguns desses posicionamentos são, inclusive, costumeiramente percebidos como extremistas/radicais (ou interpretados de forma pejorativa como excessivamente vanguardistas) ou, de modo oposto, são compreendidos sob a insígnia do conservadorismo (interpretados como intolerantes, discriminatórios ou preconceituosos). Assim, posicionamentos dissonantes encontram nas redes a possibilidade de externar suas ideias encontrando ressonância e fomentando a produção de novos vocabulários e sentidos para as noções e práticas sociais. Nesse contexto, é possível perceber como os sujeitos se pensam e sustentam posicionamentos políticos. Noções sobre resistência e vulnerabilidade são importantes e, ao mesmo tempo, utilizadas de modo ambíguo. Para Judith Butler (2014), ao longo do tempo se tem lidado com dois sentidos de resistência:

[...] resistência à vulnerabilidade que pertence a determinados projetos de pensamento e certas formações de políticas organizadas através de um domínio soberano, e uma resistência às injustiças e regimes violentos que mobiliza vulnerabilidade como parte de seu próprio exercício do poder $^{13}$. (p.18)

Para uma compreensão mais atual, a autora propõe que,

13 Tradução livre do inglês. 
[...] a cena de vulnerabilidade é uma em que há sempre um campo de força no qual qualquer criatura é exposto e que inclui seres humanos e seus homólogos animais. Não é uma característica subjetiva do ser humano nem é precisamente uma condição existencial. Ela nomeia um conjunto de relações entre os seres sensoriais e o campo de força de objetos, organizações, processos vitais e instituições que constituem a possibilidade de vida que possa ser vivida. E essas relações envolvem invariavelmente graus e modalidades de receptividade e capacidade de resposta que, trabalhando em conjunto, não formam precisamente uma sequência. (p.18).

Isso implica em reconhecer que a exposição dos corpos - via imagens, opiniões, comentários, relatos de experiência, entre outros - nas mídias digitais implica tanto na exposição das mais diversas vulnerabilidades - de si ou do outro - quanto na produção, por vezes simultânea, de diversas em formas de resistência que tornam a vida vivível e viabilizam precisamente a possibilidade de resistir. É possível deduzir, a partir desta leitura de Butler e da discussão sobre vulnerabilidade: a autora nos dá um exemplo de como a praça não é necessariamente o espaço público, mas a praça se converte em espaço público quando é apropriada pelo coletivo. Seguindo a pista fornecida por Hanna Arendt, a autora aponta para um entendimento de política como uma apropriação coletiva. A partir desta leitura torna-se viável, ainda, pensar em como a internet se converte através de seus usos em um espaço público, especialmente quando é apropriada e ocupada para uma demanda política do coletivo.

\section{LIBERDADE DE EXPRESSÃO X DISCURSO DE ÓDIO}

Uma das questões centrais suscitada pelos debates e disputas que ocorrem atualmente nas mídias digitais, assim como fora delas, concerne à liberdade de expressão enquanto direito fundamental previsto na Constituição Federal e compreendido como fundamento democrático e, também, acerca dos limites do uso deste direito (Dallari, 1994). Aqui especificamente cabe uma reflexão sobre como se articula a produção do discurso de ódio para com determinadas minorias sociais. Se por um lado as redes sociais propiciam encontros e possibilidades de (re)conhecimentos de uma ampla gama de indivíduos e/ou coletividades, por outro, também propicia a organização e veiculação de discursos ofensivos e/ou questionadores dos direitos sociais.

O importante e democrático direito à liberdade de expressão é comumente confundido com a ausência de barreiras para o conteúdo expresso. Se por um lado a lei garante a possibilidade de falar-se o que se deseja, também versa sobre os limites do conteúdo daquilo que se expressa ao versar sobre o dano moral ou material, sobre a restrição do anonimato e a inviolabilidade da intimidade, da vida privada, da honra e da imagem da pessoa. Isto pode ser lido com facilidade no texto da lei magna: 
Art. 5 Todos são iguais perante a lei, sem distinção de qualquer natureza, garantindo-se aos brasileiros e aos estrangeiros residentes no País a inviolabilidade do direito à vida, à liberdade, à igualdade, à segurança e à propriedade, nos termos seguintes:

I - homens e mulheres são iguais em direitos e obrigações, nos termos desta Constituição;

II - ninguém será obrigado a fazer ou deixar de fazer alguma coisa senão em virtude de lei; (...)

IV - é livre a manifestação do pensamento, sendo vedado o anonimato;

V - é assegurado o direito de resposta, proporcional ao agravo, além da indenização por dano material, moral ou à imagem;

VI - é inviolável a liberdade de consciência e de crença, sendo assegurado o livre exercício dos cultos religiosos e garantida, na forma da lei, a proteção aos locais de culto e a suas liturgias; (...)

IX - é livre a expressão da atividade intelectual, artística, científica e de comunicação, independentemente de censura ou licença;

$X$ - são invioláveis a intimidade, a vida privada, a honra e a imagem das pessoas, assegurado o direito a indenização pelo dano material ou moral decorrente de sua violação; (...)"14 (BRASIL, 1988).

Judith Butler (1997) apresenta uma discussão bastante densa sobre a liberdade de expressão, a democracia e os limites do discurso de ódio a partir da análise da Primeira Emenda estadunidense. Embora fale de outro contexto, há ressonâncias entre o trabalho da autora e o debate que se desenha hoje no país acerca dos limites da liberdade de expressão quando se torna discurso de ódio (hate speech). Um dos argumentos da autora é o de que o discurso de ódio não apenas comunica uma ideia ofensiva - sobre o gênero, as sexualidades ou raça/etnia - mas também confere certa concretude aquilo que comunica. Importa a este debate, focado no caso brasileiro, os embates políticos em torno da conformação de uma legislação própria para regular as ofensas proferidas via internet. Nesse cenário, recentemente, o governo federal tem dado mostras de um esforço significativo para conter o discurso de ódio na rede. Um dos exemplos disso é o debate acerca do Marco Civil da Internet, que consolidou-se no texto da Lei $n=12.965$, de 23 de abril de $2014^{15}$, conforme pode ser lido a seguir, que "Estabelece princípios, garantias, direitos e deveres para o uso da Internet no Brasil" e que, em consonância com o que está previsto na Constituição Federal de 1988 , entende que

\footnotetext{
${ }^{14}$ Fonte: Constituição Federal do Brasil (1988), TíTULO II - Dos Direitos e Garantias Fundamentais; CAPÍTULO I Dos Direitos e Deveres Individuais e Coletivos.

${ }^{15}$ Disponível em: http://www.planalto.gov.br/ccivil_03/_ato2011-2014/2014/lei/l12965.htm. Acesso em 10 de ago. 2015.
} 
Art. 2ㅇ A disciplina do uso da internet no Brasil tem como fundamento o respeito à liberdade de expressão, bem como: (...) II - os direitos humanos, o desenvolvimento da personalidade e o exercício da cidadania em meios digitais; III - a pluralidade e a diversidade.

Outra esfera que importa a este debate refere-se ao modo como o Poder Judiciário vem tratando destas questões. Nesse sentido, conforme Rosane Leal da Silva et. al. (2010), em artigo acerca de como o sistema judiciário tem julgado litígios e produzidos jurisprudências acerca dos discursos de ódio proferidos nas redes sociais,

[...] o Poder Judiciário Brasileiro vem tratando os discursos de intolerância, manifestos ou não no ambiente virtual, de maneira repressiva. As decisões tomadas deram-se pela limitação do alcance da liberdade de expressão em favor da dignidade da pessoa humana, demonstrando a dimensão negativa, defensiva, desse atributo (p. 462).

Além das instâncias legal e jurídica, é preciso levar em conta o modo como a internet propicia é acolhida pelos/as usuários/as brasileiros/as. Sugiro que o seu caráter atrativo se deva ao fato de que para muitos/as usuários/as, a rede constitui uma esfera democrática e uma arena pública propícia ao embate e com a qual não é habitual lidarmos. A revelia, suscita também o extremismo por parte de sujeitos e coletividades menos afeitos as expressões de gênero e da sexualidade não heterocentradas.

Ainda, é preciso pensar sobre o que Tatiana Lionço (2012) explicita acerca da política da vergonha, ou como a vergonha vem sendo utilizada como instrumento de opressão, atualmente em voga em falas de indivíduos que, por vezes, ocupam posições das mais conservadoras às mais vanguardistas:

precisamos lutar pelo bom uso da palavra. Sabendo que o consenso moral muitas vezes é inviável, dada a diversidade de modos de vida e mesmo de princípios morais, sejam estes religiosos ou não, devemos decidir e exigir que se use bem as palavras para que, ao invés de injúrias e alegações de imoralidade e desumanização, possamos enunciar ideias éticas que proponham a paz civil entre os grupos em sua distinção. A vergonha não deve ser um argumento político em uma democracia. A vergonha pública é tão somente um sintoma, é a expressão sem pudor da legitimação da violência que nos choca no cotidiano da intolerância consentida. (s/p).

Dito isto, cabe aventar em que medida o anonimato ou a liberdade de escrever o que se deseja sem um confronto face-a-face com o outro é capaz de romper com a hierarquia pré-estabelecida dos lugares de fala. 


\section{COMENTÁRIOS DE INTERNET E SOCIABILIDADES}

Conforme Nancy Baym (2011), diversos estudos sobre relacionamentos de amizade em redes sociais apontam para a existência de certa ambiguidade entre relações, de diversos níveis, estabelecidas on e off-line. É possível afirmar, nesse contexto, que há um relaxamento nos parâmetros de definição de relações estabelecidas no âmbito virtual. Ao contrário, tem-se mais cuidado ao estabelecer relações face a face, incluso com relação ao conteúdo. Aparentemente, tomam-se mais cuidados em estabelecer relações no off-line, em especial no que concerne aos afetos e às situações que possam causar embaraços. Destarte, este contexto informa uma série de reconfigurações que afetam as formas como diferentes indivíduos se colocam frente ao mundo e às regras sociais. Assim, o lugar de autoridade da fala de certos sujeitos passa a ser questionado enquanto outros, antes sem voz, podem alvorar-se a ocupar o espaço de quem quer e tem a possibilidade de falar. A autoridade de artistas, intelectuais, líderes religiosos passa a ser posta em cheque em diferentes contextos. Aquilo que antes era blindado pelos pudores de expressar-se publicamente passa a ter lugar nas páginas pessoais ou nos comentários de páginas da internet.

Mesmo que questionados os limites éticos ou que se preocupe com o teor discriminatório de algumas dessas falas, há algo acontecendo a partir desses espaços que desenha novos contornos às expectativas sobre uma espécie de silêncio resignado de quem discorda alguma questão. Um dos efeitos engendrados nesse cenário é um tensionamento na ideia de representação. O sujeito que tem voz não quer que sua fala seja proferida a partir de outro sujeito. Nesse contexto, podem-se ver diversos embates, mesmo dentro da academia, sobre quem pode e se é possível falar sobre que sujeitos. O subalterno, que não tinha voz ou não era ouvido (Spivak, 2010) reivindica seu espaço de fala para falar sobre suas experiências e o direito de ter a verdade sobre si. É o caso, por exemplo, do embate recente entre ativistas transfeministas e pesquisadores/as não-trans ${ }^{16}$ da temática trans no Brasil. Outro exemplo seria o não reconhecimento dos movimentos feministas radicais das

16 Classificados a partir da categoria cisgênero pelas pessoas trans. $O$ termo parece indicar/pressupor/denunciar uma coerência entre o sexo assignado ao nascer e a identidade de gênero manifesta/vivida das pessoas não trans - o que, em si, traduzir-se-ia em um privilégio para estas pessoas nas diversas dimensões de suas vidas. Parece, contudo, que a definição exata e o uso do termo tem se dado de forma polissêmica. Já pude ouvir, em uma palestra, uma travesti afirmar que o uso do termo trata-se de uma "importação" que é um "tiro no pé", uma vez que reatualiza a hierarquia e distinção entre pessoas trans e nãotrans, deixando as primeiras em situação de inferioridade. Assim, penso, a emergência desta categoria, seus sentidos e usos na vida social - sobretudo no contexto brasileiro - ainda precisam ser mais bem pesquisados e compreendidos. 
identidades de mulheres trans como mulheres ${ }^{17}$. Ainda, das tensões produzidas através de campanhas que denunciam assédios sofridos por mulheres em diferentes espaços e de diferentes pessoas ao longo de suas vidas como a \#meuprimeiroassedio e a \#meuamigosecreto; sobretudo a partir da recusa de certos grupos de mulheres - que se percebem como feministas ou não - de abrir este espaço de fala para homens compartilharem suas experiências ou apoios a estas estratégias de luta ${ }^{18}$.

No contexto das relações digitalmente mediadas, diferentes sujeitos assumem um protagonismo acerca do discurso de si (Sibilia, 2008) ou dos discursos sobre a vida em geral a partir da criação de espaços de fala que não existiam anteriormente. É preciso pontuar que estamos falando do Brasil e que nosso país tem uma formação social calcada no autoritarismo e na hierarquia e, portanto, é nesse ponto que as mídias podem emergir como uma experiência - por vezes primária - democrática. O revés disso é justamente a ausência de parâmetros que limitem o discurso. $O$ que quero dizer é que as pessoas acham que por ser democrático podem falar o que quiserem sem consequências maiores. Mas se esquecem de que é justamente a democracia que garante o revide e o direito ao contraditório como peças fundamentais para o seu funcionamento.

Nesse contexto, os impactos da criação desses espaços de fala antes impensáveis implicam também em uma reestruturação de espaços de autoridade, em que saberes são continuamente questionados, assim como a própria legitimidade da hierarquia. Se antes a crítica social, jocosa e/ou ofensiva era circunscrita ao espaço da piada e do carnaval, hoje ela pode ser proferida com a mesma velocidade com que se tem contato com uma informação.

Um exemplo dessa nova velocidade com que as coisas acontecem são os memes, que como instrumentos de crítica tem um poder e lugar central atualmente e que são pouco analisados. Memes são vídeos, imagens, expressões, frases, etc., que com frequência se espalham de forma viral (muito rapidamente) entre usuários/as da internet e adquirindo grande popularidade nas redes sociais. Em geral são pastiches e paródias produzidas a partir de cópias, metáforas ou imitações de fatos ocorridos e/ou publicados na rede. Conforme Martino (2015), contudo, há de se distinguir memes de virais:

\footnotetext{
${ }^{17}$ A partir de um discurso de entende que nascer mulher remonta a uma condição de subordinação a que todas as mulheres seriam submetidas. Diferente do que se chamou de segunda onda do feminismo (Piscitelli, 2009, Vencato \& Vieira, 2014), contudo, essa subordinação universal pode ser matizada a partir da sexualidade, da classe ou da raça/etnia, produzindo indivíduos mais ou menos excluídos.

18 Todos estes exemplos mereciam ser melhor explorados em trabalhos específicos e, penso, deveriam ser melhor trabalhados na literatura sobre gênero, sexualidades e movimentos sociais na contemporaneidades. Por fugirem ao pretendido para este texto, cito-os apenas como exemplos de tensões atuais que podem ser percebidas em diversos espaços nos últimos anos.
} 
Embora sejam muitas vezes usados como sinônimos, há algumas diferenças significativas entre memes e virais. Nos dois casos, trata-se de elementos que podem se espalhar nos ambientes virtuais. A lógica da difusão é semelhante: um vídeo, texto ou imagem é reproduzido milhões de vezes, podendo se espalhar para locais e contextos muito diferentes do original.

Há uma diferença, no entanto: enquanto os virais tendem a ser reproduzidos milhares de vezes em sua forma original, os memes geralmente são modificados de inúmeras formas no processo de replicação. (p. 179)

Contudo, nos alerta o autor, é preciso que se diga que não há uma rigidez nesta separação pois um viral pode vir a se tornar um meme caso sofra modificações a partir de algum ponto de sua imprevisível difusão.

É possível afirmar que para compreender quaisquer memes, é necessário estar imerso no universo simbólico dos grupos ou indivíduos que os elaboram. Isso porque, há de se considerar, conforme Donna Haraway (2016), que

as tecnologias e os discursos científicos podem ser parcialmente compreendidos como formalizações, isto é, como momentos congelados das fluidas interações sociais que as constituem, mas eles devem ser vistos também como instrumentos para imposição de significados. a fronteira entre ferramenta e mito, instrumento e conceito, sistemas históricos de relações sociais e anatomias históricas dos corpos possíveis (incluindo objetos de conhecimento) é permeável. Na verdade, o mito e a ferramenta são mutuamente constituídos. (p.64)

Só a partir desse embasamento é possível visualizar os deslizes semânticos e as torções da linguagem mediante a ironia, o humor e o pastiche que os memes contêm. Nesse contexto, principalmente aquelas pessoas que sempre tiveram o privilegio de falar com autoridade - como intelectuais, artistas, jornalistas e outros - tem seu lugar de fala ou ideais questionados de forma nunca antes vista, em uma possibilidade de (re)interpretação do ato de fala praticamente infinita e que é, ao mesmo tempo, continuamente reelaborada.

É possível sugerir que os memes não passam pela mesma linguagem autorizada $d x s$ acadêmicxs ou da imprensa jornalística e, por este motivo tornam-se ferramenta tão poderosa. Enquanto o discurso acadêmico polido exige um conjunto de leituras previas articuladas para produzir sentido, os memes se valem dos sentidos instalados torcendo-os. Ao mesmo tempo em que o discurso jornalístico se propões um relato de "fatos reais" os memes problematizam este senso de verdade a partir de diferentes olhares e leituras possíveis sobre um mesmo episódio. É justamente isso que, por vezes, os torna muito mais poderosos, na medida em que se valem das experiências cotidianas para fundamentar a sua crítica. 


\title{
CONSIDERAÇÕES FINAIS
}

Conforme Luís Mauro Sá Martino (2015), diferentes pesquisas vem trabalhando com enfoques distintos às intersecções entre política, ciberespaço e mídias digitais. Em certos casos, o que é tido como política por um autor sequer seria considerado um objeto válido de estudo para outros. Seguindo a pista fornecida pelo autor, optei ao longo deste texto por uma concepção mais ampla - ou menos tradicional - de política que, nas mídias digitais,

\begin{abstract}
[...] relaciona-se com diversas manifestações e afirmações da identidade, na disputa pela chance de chamar a atenção de outras pessoas para problemas sociais diversos, procurando não apenas o engajamento, mas também a visibilidade. Isso significa aparecer em público e dar mais espaço para uma causa, reivindicação ou problema. Um blog ou perfil em rede social que marque posição a respeito de um estilo de vida pode ser entendido como um ambiente político - a identidade, em público, torna-se um problema político. (Martino, 2015, p. 86)
\end{abstract}

Se em uma perspectiva clássica a ideia de Esfera Pública "[...] pode ser entendida como um espaço de ação social formado na interação entre pessoas" (Martino, 2015, p. 90) e compreendendo que a "opinião pública" não se traduz apenas a partir da "opinião do público" e, sim, a partir de um conjunto de pontos de vista que são levados a público e discutidos coletivamente com quaisquer indivíduos que estejam interessados em dado tema. Aqui é possível inferir que qualquer debate que pode eventualmente embasar consensos só se torna possível a partir da existência de espaços em que seja factível a livre manifestação de ideias (Martino, 2015). Assim, para a constituição da Esfera Pública há um elemento-chave fundamental e este se trata

[...] de um espaço de discussão de temas de caráter político, isto é, que dizem respeito ao indivíduo como cidadão dentro de um Estado regulado pelo Direito. Os temas da Esfera Pública se caracterizam pelo engajamento que provocam, ou deveriam provocar, nas pessoas. Não se trata, portanto, do simples interesse que um tema tem, mas da relevância que esse tema poderia assumir dentro da democracia. (Martino, 2015, p.95)

Nesse contexto de novos protagonismos na internet e de ocupação de lugares de fala por aqueles sujeitos que antes tinham pouca ou nenhuma voz, uma infinidade de expressões de jocosidades, acusações, ofensas ou produções de discursos sobre a própria experiência, sobre o gênero e as sexualidades têm aparecido como centrais para a compreensão das sociabilidades contemporâneas. Há uma evidente profusão de vozes e ideias, que vão das falas que defendem o direito à identidade até aquelas que o negam, que tornam possível observar um amplo campo de disputas acerca dos sentidos da verdade assim como de seu questionamento. 
Assim, propus-me a pensar, para além da emergência de novos sujeitos políticos que reivindicam outras identificações para além das já estabelecidas (em especial quanto às por vezes reclamadas identidades fixas relativas ao gênero e às sexualidades), na ampliação do debate sobre "liberdade de expressão $x$ discurso de ódio", assim como no modo pelo qual aumentam as estratégias e usos de formas de controle social aos direitos daqueles indivíduos tidos como "fora da norma" de viverem suas vidas sexuais e afetivas a partir de seus desejos.

Entendo, conforme Judith Butler (2003), que a.

[...] "coerência" e a "continuidade"' da 'pessoa' não são características lógicas ou analíticas da condição de pessoa, mas, ao contrário, normas de inteligibilidade socialmente construídas ou mantidas. Em sendo a "identidade" assegurada por conceitos estabilizadores de sexo, gênero e sexualidade, a própria noção de "pessoa" se veria questionada pela emergência cultural daqueles seres cujo gênero é "incoerente" ou "descontínuo", os quais parecem ser pessoas, mas não se conformam às normas de gênero da inteligibilidade cultural pelos quais as pessoas são definidas. Gêneros 'inteligíveis' são aqueles que, em certo sentido, instituem e mantêm relações de coerência e continuidade entre sexo, gênero, prática sexual e desejo. (p. 38).

Talvez, apesar dos prognósticos pessimistas acerca do aumento de falas interpretadas como contrárias ao direito a diferença, o que esteja se delineando é justamente a possibilidade de colocarmos em cheque a ideia de uma verdade absoluta e a produção social de um discurso que relativiza qualquer possibilidade de verdade acerca do gênero, das sexualidades ou de quaisquer outras instâncias da vida.

\section{REFERÊNCIAS:}

BAPTISTA, Luis Antonio dos Santos. A Atriz, o Padre e a Psicanalista - os Amoladores de Facas. In: A Cidade dos Sábios. São Paulo, SP: Summus, 1999. p. 45 a 49. Disponível em: https://goo.gl/WTC8qn. Acesso em 11 de agosto de 2015.

BAQUERO, Marcello. Democracia formal, cultura política informal e capital social no Brasil. Opin. Publica, v. 14, n. 2. Campinas, SP: Nov. 2008. p. 380-413. Disponível em: https://goo.gl/cV6hPg. Acesso em 02 Nov. 2016.

BAYM, Nancy K. Social Networks 2.0. In: CONSALVO, Mia \& ESS, Charles. (Eds.). The Handbook of Internet Studies. Blackwell: US/UK, 2011. p. 384-405.

boyd, danah m., ELLISON, Nicole B. Social Network Sites: Definition, History, and Scholarship. Journal of Computer-Mediated Communication, V. 13 (1), Out. 2007. p. 210230. Disponível em: https://goo.gl/UMT8y.

BRASIL. Constituição Federal (1988). Disponível em: https://goo.gl/HwJ1Q. Acesso em 10 de agosto de 2015. 
BRASIL. LEI № 12.965, DE 23 DE ABRIL DE 2014. Disponível em: https://goo.gl/fj8a4q. Acesso em 10 de agosto de 2015.

BUTLER, Judith. Excitable Speech: A politics of the performative. Nova lorque/Londres: Routledge, 1997.

BUTLER, Judith. Problemas de Gênero: Feminismo e Subversão da Identidade. Rio de Janeiro, RJ: Civilização Brasileira, 2003.

BUTLER, Judith. Rethinking Vulnerability and Resistance. [mimeo]. Madri: Jun. 2014. Disponível em: https://goo.gl/iErmM3. Acesso em 23 fev. 2016.

DALLARI, Dalmo. $O$ que são direitos da pessoa. 10 ed. São Paulo, SP: Brasiliense, 1994.

DOSSIÊ "Forum 2014 Elections". Bras. Political Sci. Rev. vol. 9 n. 1. São Paulo, SP: Jan./Apr. 2015. Disponível em: https://goo.gl/t3x9VP. Acesso em: 31 de outubro de 2016.

GLUCKMAN, Max. Análise de uma situação social na Zululândia moderna. In FELDMANBIANCO, Bela (org.). Antropologia das Sociedades Contemporâneas. São Paulo, SP: Global Universitária, 1987. pp.227-344.

HARAWAY, Donna. Manifesto ciborgue: ciência, tecnologia e feminismo-socialista no final do século XX. HARAWAY, Donna, KUNZRU, Hari, TADEU, Tomaz (orgs.). Antropologia do ciborgue: as vertigens do pós-humano. 2 ed. Belo Horizonte, MG: Autêntica, 2016. p. 33118.

LIONÇO, Tatiana. O pertencimento pelo reconhecimento: contra a política da vergonha. Câmara em Pauta, 14/11/2012. Disponível em: https://goo.gl/TS91Jv. Acesso em 11 de agosto de 2015.

MARTINO, Luís Mauro Sá. Teoria das Mídias Digitais: linguagens, ambientes e redes. Petrópolis, RJ: Vozes, 2015.

McQUIRE, Scott. A casa estranhada. Revista do Programa de Pós-graduação da Escola de Comunicação da UFRJ. Dossiê: cidades midiáticas. V. 14, n. 01 . Rio de Janeiro, RJ: UFRJ: 2011. pp. 27-66.

PADILHA, Felipe A. O segredo é a alma do negócio: mídias digitais móveis e a gestão da visibilidade do desejo homoerótico entre homens na região de São Carlos. Dissertação. São Carlos, SP: PPGS/UFSCar, 2015. Disponível em: https://goo.gl/sb9UJw. Acesso em: 23 out. 2015.

PISCITELLI, Adriana. Gênero: a história de um conceito. In: ALMEIDA, Heloísa Buarque de. SZWAKO, José. Diferenças, igualdades. São Paulo, SP: Berlendis \& Vertecchia, 2009. p. 116149.

RECUERO, Raquel. O twitter como esfera pública: como foram descritos os candidatos durante os debates presidenciais do 2 o turno de 2014?. Rev. bras. linguist. apl. v. 16, n. 1.

(C) ETD- Educação Temática Digital $\quad$ Campinas, SP $\quad$ v.19 $\quad$ n.4 $\quad$ p. 808-823 $\quad$ out./dez. 2017 
Belo Horizonte, MG: Mar. 2016. p. 157-180. Disponível em: https://goo.gl/o7DLea. Acesso em 01 de novembro de 2016.

SAKAMOTO, Leonardo. A homofobia de Levy Fidelix doeu tanto quanto o silêncio dos candidatos. Blog do Sakamoto, 29 de setembro de 2014. Disponível em: https://goo.gl/R5cdZq. Acesso em 11 de agosto de 2015.

SAKAMOTO, Leonardo. Caso Levy: A diferença entre emitir opinião e proferir discurso de ódio. Blog do Sakamoto, 30 de setembro de 2014. Disponível em: https://goo.gl/kG5Fnu. Acesso em: 11 de agosto de 2015.

SIBILIA, Paula. O show do eu: a intimidade como espetáculo. Rio de Janeiro, RJ: Nova Fronteira, 2008.

SILVA, Rosane Leal da; NICHEL, Andressa; MARTINS, Anna Clara Lehmann; BORCHARDT, Carlise Kolbe. Discursos de ódio em redes sociais: jurisprudência brasileira. Rev. direito GV, v. 7, n. 2. São Paulo, SP: Dez. 2011. p. 445-468. Disponível em: https://goo.gl/ELzmDb. Acesso em: 31 de outubro de 2016.

SPIVAK, Gayatri Chakravorty. Pode o subalterno falar? Belo Horizonte, MG: UFMG, 2010. VENCATO, Anna Paula, CORRÊA VIEIRA, Regina Stela. Divisão sexual do trabalho. História do movimento feminista. In: MOTTA, Flávia de Mattos (org.). Cotidiano escolar: relações de gênero e profissão docente (livro didático). Palhoça: UnisulVirtual, 2014. p. 25-48.

\section{Agradecimentos $^{i}$}

Uma versão preliminar deste texto foi apresentada na a Mesa-Redonda: "Gênero, sexualidade e direitos, diálogos e tensões com a mídia", coordenada por Larissa Pelúcio, da XVII Jornada Multidisciplinar "Diversidade, Acessibilidade e Direitos: diálogos com a comunicação" - UNESP/Bauru em 2015. Uma segunda versão, revisada e ampliada, foi apresentada no grupo de trabalho "Antropologia Digital, Tecnologia e Cibercultura", coordenado por Débora Krischke Leitão e Laura Graziela Gomes, da 30ạ Reunião Brasileira de Antropologia - UFPB/João Pessoa em 2016. Agradeço às professoras-coordenadoras Larissa, Débora e Laura pela oportunidade de submeter este texto ao debate. Agradeço a Felipe A. Padilha pelas inúmeras leituras críticas do texto e indicações de leituras sobre mídias digitais. Agradeço a Fernanda Vencato e Regina Stela Corrêa Vieira pela leitura e sugestões no que concerne à legislação brasileira.

\footnotetext{
' Revisão gramatical do texto sob a responsabilidade dos autores
}

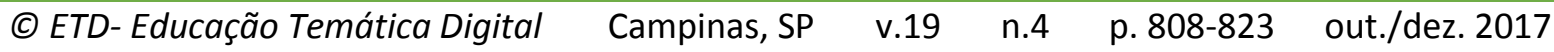

